\title{
E-Commerce Adoption Factors in Saudi Arabia
}

\author{
Dr. Sulaiman Al-Hudhaif (Corresponding author) \\ Vice Dean for Quality and Development \\ Associate Professor-Department of Management Information System \\ College of Business Administration, King Saud University \\ P.O Box 86924, Riyadh 11632, Saudi Arabia \\ Tel: 966-1-467-4382Ｅ-mail: shudhaif@ksu.edu.sa \\ Abdullah Alkubeyyer \\ Strategic PMO Methodology Manager, Saudi Telecom Company \\ P.O. Box 86072, Riyadh 11622, Saudi Arabia \\ Tel: 966-1-443-1822Ｅ-mail: kubeyyer@gmail.com
}

Received: March 21, 2011 Accepted: May 6, 2011 doi:10.5539/ijbm.v6n9p122

\begin{abstract}
Some sectors in Saudi Arabia are slow in adopting eCommerce technologies for running their business transactions, and that is due to an internal set of factors (related to organizations) or an external set of factors (related to infrastructure and governmental support). We have noticed that most of the studies in this subject covered either internal factors or external factors, but not both. Moreover, most of the papers that studied eCommerce adoption factors in developing economies center on the environmental, infrastructural and governmental areas only, and overlook the organizational factors, while the focus of the subject studied and researched on developed economies was organizational (SMEs and large enterprises) related adoption factors by considering the technology infrastructure and government support as taken for granted, which is not the case in developing economies.

The objectives of this study are 1) to find out the level of eCommerce adoption in Saudi Arabia, and 2) to identify the factors that affect the adoption of eCommerce. By this, the output of the study can help the policy maker of ICT (Information and Communication Technology) in Saudi Arabia to direct the related activities toward the most effective local factors that will enable and leverage eCommerce potential and usage on one hand, and on the other hand the study will identify the promising local opportunities for eCommerce infrastructure providers (local banks, system integrators, IT solution providers, and major telecom operators) by discovering the distinctive eCommerce adoption factors.
\end{abstract}

Keywords: eCommerce, ICT, Saudi Arabia, Internal adoption factors, External adoption factors, PERM, Developing economies, Developed economies

\section{Introduction}

In developed economies, eCommerce and B2B have been in general successful and a valid option for expanding the eCommerce market either by Clicks-Pure-Play, or Clicks-and-Bricks-Mixed-Play. This research focuses on the eCommerce adoption factors in Saudi Arabia.

One of the active and dynamic industries in Saudi Arabia is the retail sector; it is the fourth largest sector in the country after oil, banking, and telecommunication sectors. In 2008, the retail sales were around USD 55 Billion, and expected to reach USD 97 Billion by 2013. On that basis, local banks recently started to provide e-payment gateway solutions, and telecom operators are concentrating their strategies on broadband as well as CITC (Communication and Information Technology Commission), which has adopted a cooperative strategy between the related parties (government agencies, media players, telecom operators, and educational bodies in the country) to leverage the broadband based economy, mainly the eCommerce.

Therefore, the focus is on adoption factors (barriers and motivators), which will provide the guidance for answering the research question "what are the eCommerce adoption factors in Saudi Arabia?" By such questions, the study will cover both internal (microenvironment) adoption factors as well as external (macroenvironment) adoption factors.

In addition to the above question, the eCommerce adoption level in Saudi Arabia will also be captured during 
collecting and studying the data of the adoption factors.

\subsection{Study Objectives}

This paper aims to achieve three objectives:

- To find out the level of eCommerce adoption in Saudi Arabia

- To identify the factors that affect and contribute to the level of adoption of eCommerce

- To identify the distinctive factors for initial adoption of eCommerce and then its institutionalization

\section{Literature Review}

It has been widely recognized that the adoption and diffusion of eCommerce by businesses in developing countries is an important economic indicator of growth due to the perceived potential of the internet in reducing transaction cost (Molla and Licker, 2005), however the adoption of eCommerce in developing countries has fallen below expectation, and there have been several studies to explain the barriers and motivators (Molla and Licker, 2005). There are a very few analytical eCommerce studies in the developing countries (Davis, 1999; Enns and Huff, 1999; Jennex and Amoroso, 2002; Mukti, 2000; Moodley and Morris, 2004). Most of the studies focused on macro level and environmental constraints (physical, technological, institutional and socio-economical eReadiness and eCommerce barriers), but that should not be considered as the only source of barriers; from the literature of developed countries regarding eCommerce adoption decision, they are influenced by organizational readiness (the managerial, organizational and eCommerce related resources) (Beatty, Shim and Jones, 2001; Daniel and Grimshaw, 2002). The only comprehensive model (Molla and Licker, 2005) by Molla and Licker that focuses on developing countries covers both environmental and organizational readiness.

The objective of this study is to identify the obstacles that prevent the adoption of eCommerce as a retail channel in Saudi Arabia. The literature review would therefore concentrate more on the areas of eReadiness and adoption of eCommerce in the context of developing countries (Saudi Arabia as a case)

\section{1 eTailer}

eTailer is defined (Laudon and Traver, 2010) as "online retail store", and this research would follow that, but many researchers have developed their own definitions similar to the one mentioned above, and some have noted that the eTailer is the same as B2C eCommerce (Kuhl and Beckmann, 1985; Davis, 1989). However, eTailing is not restricted to transactions with individuals (consumers) only; there could be a business transaction with other enterprises, and therefore eTailer should not be narrowed to B2C eCommerce type, but rather it should be viewed as the final point in the supply chain that is facing the end customer (whether individual consumer, or business customer).

\subsection{1 eTailing business model}

There are four main types of online retail business models (Laudon and Traver, 2010):

- Virtual Merchants: Single channel Web firms that generate almost all of their revenue from online sales.

- Multi-channel Merchandisers (Bricks-and-Clicks): companies that have a network of physical stores as their primary retail channel, but also have introduced online offerings

- Catalogue Merchants: established companies that have a national offline catalogue operation that is their largest retail channel but who have recently developed online capabilities.

- Manufacture-direct: single or multi-channel manufactures who sell directly online to consumers without the intervention of retailers.

\section{2 eCommerce in Developing Countries}

Because of the usual lack of the necessary financial, legal, and physical infrastructures for eCommerce in developing countries, the adoption of eCommerce in developing countries differs significantly from developed countries. Developing countries often have different business practices and cultures, which limit the applicability and relevance of the eCommerce models designed for developed countries (Gibbs, Kraemer and Dedrick, 2003; Hemple and Kwong, 2001; Molla and Licker, 2005). Additionally, most businesses in developing countries are small and thus less complex, which could facilitate eCommerce adoption, but that could also indicate the lack of sufficient resources required to invest in eCommerce (Goode and Stevens, 2000).

\subsection{Theoretical Background}

The literature on eCommerce adoption suggests that most research is based on one of the following frameworks:

1) Diffusion of innovation (DOI) (Beatty, Shim and Jones, 2001; Mehrtens, Cragg and Mills, 2001; Rogers, 1995; Zhu and Kraemer, 2005).

2) The Theory of Planned Behaviour (TPB) (Kuhl and Beckmann, 1985).

3) Technology Acceptance Model (TAM) (Davis, 1989).

4) The Technology-Organization-Environment Model (TOE) (Kuan and Chau, 2001; Tornatzky and 
Fleischer, 1990; Xu, Zhu and Gibbs, 2004; Zhu and Kraemer, 2005).

5) Institutional theory (Chatterjee, Grewal and Sambamurthy, 2002).

6) Resource-based theory (Barney, 1991; Zhu and Kraemer, 2005).

Several models have been developed on these frameworks. These models have different focuses, and are designed to examine different aspects of eCommerce adoption. Some models examine only the external environment of firms (Gibbs, Kraemer and Dedrick, 2003; Hemple and Kwong, 2001; Kshetri and Dholakia, 2002), while some consider technological aspects (Claycomb, Iyer and Germain, 2005).

Most of these models and studies examined one view or perspective, which can be summarized into the following:

- Perspective of adoption of innovation by individuals (organizations are too complex).

- Attributes of the innovation Perspective (advantages, compatibility, complexity).

- Managerial perspective and CEO characteristics.

- Organizational characteristics perspective.

- Environmental factors (competition, suppliers, regulatory actions).

Conversely, the models developed based on the Technology-Organization-Environment Model framework (Kuan and Chau, 2001; Xu, Zhu and Gibbs, 2004; Zhu and Kraemer, 2005) have tried to study the organizational context of eCommerce adoption. In these models, only factors such as firm size and scope are included. Others, such as managerial and internal organizational aspects (Molla and Licker, 2005) are left unevaluated, including the centralization, formalization, and complexity of managerial structure, the quality of human resources, and the amount of slack resources available internally (Xu, Zhu and Gibbs , 2004).

From the previous studies, most of these models are designed for developed countries where businesses consider it for granted that some environmental (external) services are there, such as delivery systems, credit payment, and government regulations. Thus, the Perceived eReadiness Model (PERM) developed by Molla and Licker's study (Molla and Licker, 2005) identifies many of the contextual and organizational factors that affect eCommerce adoption in developing countries (Molla and Licker, 2005). It defines two major constructs that measure both internal and external factors: Perceived Organizational eReadiness (POER) and Perceived External eReadiness (PEER) (Molla and Licker, 2005).

POER is defined as managers' perception and evaluation of the degree to which they believe that their organization has the awareness, resources, commitment, and governance to adopt eCommerce (Molla and Licker, 2005). The PEER is the degree to which managers believe that market forces, government, and other supporting industries are ready to aid in their organization's eCommerce implementation (Molla and Licker, 2005) (Figure 1).

The theoretical root of this model is interactionism, which allows a multi-perspective audit of the managerial, internal organizational, and external contextual issues to provide meaningful predictors of eCommerce adoption in developing countries (Molla and Licker, 2005).

The PERM Model is more comprehensive than earlier models, because it includes both external environmental and internal organizational issues (Molla and Licker, 2005). It is more relevant, because it is designed for developing countries (Molla and Licker, 2005), compared with previous studies of e-commerce adoption factors in Saudi market, where the focus is on either external environment or end-user perspective.

PERM model identifies two levels of adoption, the initial adoption of eCommerce, and the institutionalization of eCommerce (Molla and Licker, 2005).

The definitions of the model's variables are listed in table 12 . We believe, however, that we should redefine the dependant variable "eCommerce Adoption level" and its values of categories of the dependant variable as the following:

eCommerce Adoption levels are:

Non-Adopters:

1) Not connected to the internet, no email.

2) Connected with email but no web site.

Initial Adopters:

1) Static eCommerce, that is, publishing basic company information on the web without any interactivity.

2) Interactive eCommerce that accepts queries, email, and form entry from users.

3) Institutional Adopters:

4) Transactive eCommerce, that is, online selling and purchasing of products or services, including customer services. 
5) Integrated eCommerce, where the web site is integrated with suppliers, customers and other back office systems allowing most of the business transactions to be connected electronically.

We disagree with the original model of PERM in counting the first three levels $(1,2,3)$ from the above list as non-adopters. In our opinion, if a business took the step to build a static website, meaning paying the money to register a domain, and arrange for hosting and basic development (even if it is one of the free services on the internet) it would indicate a higher intention and willingness to adopt and join the highway of internet, and therefore it would be in our judgment counted as an adopter more than not.

Finally, to make the model more compatible with Saudi market and because of the lack of an institutional physical delivery system (lack of local and national home delivery services) we added one dimension to the supporting industries: eReadiness about the delivery system.

\subsection{Conclusion of Review}

It is generally agreed that online retail is the smallest segment of the retail industry (Laudon and Traver, 2010) representing about $3 \%$ of the total retail market today, but it is continuing to increase at a fast growth rate (around 14\% a year) and that not including the online services such as travel and job-hunting. Moreover, the retail sector in Saudi Arabia is one of the fastest growing industries. Answering the question of this research would identify the promising local opportunities for eCommerce infrastructure providers (local banks, system integrators, IT solution providers, and major telecom operators).

\subsection{The Questions of the Study}

Using the pioneering Molla and Licker Model (Molla and Licker, 2005) in the context of Saudi Arabia, The contributions of this paper will seek to answer the following questions:

- What is the current level of eCommerce adoption in Saudi Arabia?

- What are the distinct factors (barriers or motivators) that are more likely to affect the initial adoption of eCommerce in Saudi Arabia?

- What are the distinct factors (barriers or motivators) that are more likely to affect the institutional adoption of eCommerce in Saudi Arabia?

\subsection{The Hypothesis}

To be able to answer such questions, the following hypotheses are used to link the effect of internal and external factors to the spirit after positively to the level of eCommerce adoption:

- Hypothesis POER1: Perceived Organizational eReadiness factors contribute positively to initial adoption of eCommerce.

- Hypothesis POER2: Perceived Organizational eReadiness factors contribute positively to the institutionalization of eCommerce.

- Hypothesis PEER4: Perceived External eReadiness factors contribute positively to initial adoption of eCommerce.

- Hypothesis PEER4: Perceived Organizational eReadiness factors contribute positively to the institutionalization of eCommerce.

\section{Research Methodology}

The research has utilized the survey method by having the questionnaire from PERM, which covers 33 items of POER measured using 5-point Likert scale, 10 items of PEER using 5-points Likert scale plus one additional item regarding the supporting industries' eReadiness (in total 11 items for PEER), while using six item usage scale to measure the eCommerce adoption.

\subsection{Sampling and Data Collection}

- The population is any company operating in the Saudi local market

- The sample: we chose the top 100 Saudi companies, by targeting the Marketing and IT staff in these companies, for it is most likely that they have the leadership position in their industry.

\subsection{Data Analysis Procedure}

- The dependant variable is a categorical variable while the independent variables are intervals.

- Discriminant Function Analysis is the appropriate technique.

- The research model and the hypotheses were analyzed using Discriminant Function Analysis.

- Discriminant Function Analysis is a statistical analysis to predict a categorical dependent variable by one or more continuous or binary independent variables.

\subsection{Implementation - Questionnaire Distribution}

- On the 16th of May, the distribution of questionnaires started, and continued for two weeks using the following forms and media: 
- 150 electronic questionnaires have been distributed.

- 50 hardcopy questionnaires have been distributed.

- On the 30th of May, the reminder procedure was followed for a week.

\section{Analysis}

\subsection{Respondents and Response Rate}

By the end of deadline "7th of June 2010", 110 responses were received, 18 out of 110 responses were incomplete, therefore the total accepted responses are 92 with $46 \%$ response rate.

\subsection{Descriptive Analysis}

Of the respondents, $72 \%$ have 500 employees or more, which means the majority are large enterprises, and table 1 shows the distribution based on industry type.

View of Job titles: Managing Director, CEOs, VPs, but the majority was in managerial levels in IT, Finance, Marketing and Sales.

The status or the level of eCommerce adoption in Saudi Arabia is expressed in table2.

It is clear that none of the cases was not connected to the internet, and based on our definition of non-adopters, initial adopters, institutional adopters, we can have the following calculations:

- $6.5 \%$ are non-adopters

- $42.4 \%$ are initial adopters

- $51.1 \%$ are institutional adopters

\subsection{Reliability Analysis}

We performed a reliability test to validate the model with the local market of Saudi Arabia. The coefficient alpha and item-scale correlations have been used to test the reliability as illustrated in table3.

By reading the Cronbach's Alpha of each item, we can conclude that in general all the items are above 0.8 , the accepted cut-off for reliability, while in the corrected item total correlation there are some items that did not meet the acceptable level ( $>0.4)$ as defined in Moll's model, and these are listed below:

HR2: "Most of our employees have unrestricted access to computers" with 0.19

BR5: "Failure can be tolerated in our organization" with 0.2

SIeR2: "The technology infrastructure of commercial and financial institutions is capable of supporting eCommerce transactions" with 0.314

SIeR5: "Delivery system services are easily available and affordable" with 0.296

However, for our study and the importance of the infrastructure and delivery system, we will use a lower cut-off point of 0.25 , and by so doing we will have to reject HR2, and BR5

\subsection{Inferential Analysis - Using Discriminant Function Analysis (DFA)}

Part I: We ran the DFA using SPSS with the following input:

- Categorical dependant variable:

- eCommerce Adoption status (EAD): 1 for Non-Adopter, 2 for Initial Adoption, 3 for Institutional Adoption.

- On that basis, we have three groups, and therefore DSA should provide two functions.

- Interval independent variables:

- POER - Perceived Organizational eReadiness.

- PEER - Perceived External eReadiness .

From Test of Equality it can be seen that Wilks's lambda is significant by the $\mathrm{F}$ test for all variables (POER and PEER) $\rightarrow$ i.e., no Variable will be dropped from the Model. (Table 4)

Box's $M$ test tests (Table5) the assumption of homogeneity of covariance matrices. This test is very sensitive, to meet the assumption of multivariate normality. For the data in the table below, the test is significant, so we conclude that the groups do differ in their covariance matrices.

The model has generated two functions, and both are significant as illustrated in table 6:

By calculating the disciminant loading for each variable per each function we can get the indication of the predictors of membership as shown in table 7:

From function1: POER is identified as a significant and positive contributor to institutionalization of eCommerce, which result supports the hypotheses of POER2

From function2: PEER is identified as a significant and positive contributor to Initial adoption of eCommerce, and this result supports the hypotheses of PEER3

On that basis, the perceived external eReadiness factors are the main drivers for the initial stage of adoption; on 
the other hand, for the businesses to take the extra mile towards the institutionalized eCommerce, the perceived organizational eReadiness factors are the main drivers.

Part II: We ran the DFA using SPSS with the following input:

- Categorical dependant variable:

- eCommerce Adoption status (EAD): 1 for Non-Adopter, 2 for Initial Adoption, 3 for Institutional Adoption.

- Based on that, we have three groups, and DSA will therefore provide two functions.

- Interval independent variables:

- Internal: Awareness, Commitment, Governance, Resources (Human Resources, Business Resources, and Technology Resources).

- External: Market Forces eReadiness, Supporting Industries eReadiness, and Government eReadiness.

From Test of Equality it can be seen that Wilks's lambda is significant by the $\mathrm{F}$ test for all variables except for BR (Business Resources) (Table 8).

Box's M test tests the assumption of homogeneity of covariance matrices. This test is very sensitive, to meet the assumption of multivariate normality. For the data in table 9, the test is significant so we conclude the groups do differ in their covariance matrices.

The model has generated two functions, and both are significant as illustrated table 10:

By calculating the disciminant loading for each variable per each function we can get the indication of the predictors of membership as shown in table 11.

From function1: TR, C, A, G, MFeR, and HR are identified as significant and positive contributors to institutionalization of eCommerce

From function2: SIeR, MFeR, and GVeR are identified as significant and positive contributors to Initial adoption of eCommerce.

\section{Results}

As orientation for newcomers to the Saudi market, the level of adopting eCommerce is $51 \%$ as institutionalized and $42 \%$ as initial adopters.

The Supported Hypotheses are:

- Hypotheses POER2: Perceived Organizational eReadiness factors contribute positively to the Institutionalization of eCommerce

- Hypotheses PEER3: Perceived External eReadiness factors contribute positively to initial adoption of eCommerce

That means that the first step in adoption of eCommerce and the related decisions are heavily dependent on the external factor, mainly the factors related to market forces (customers and partner eReadiness) as well as the supporting industries eReadiness, and then the effect of government eReadiness and support will play an effective role of directing and facilitating. However, for advanced and institutional eCommerce-level decisions and adoption, the main factors and determinants are internal factors (technology resources related factors, managerial factors, organizational factors) while the only external factor that still has a considerable amount of influential power in this level of adoption is the market forces' eReadiness.

As a policy maker (Ministry of Communication and Information Technology, and Communication and Information Technology Commission) concentrating on external enablement will take firms only to the initial level of adoption. For taking the last mile, policies and strategies need to be developed with focus on the internal factors of the local firms.

Opportunities seekers and investors in the arena of eCommerce solutions must concentrate on providing the Technology resources, training for raising the awareness, commitment, and governance of firms in a specific industry, as well as analyzing the market forces of that particular industry, and help in raising such forces (from the customers, and the suppliers).

\section{Limitation and Future Work}

The current research has several limitations:

First: a larger sample would be desirable for greater results, and to test the obtained results in this study.

Second: covering more small and mid-size enterprises (SMEs) (in this study the large enterprises are $72 \%$ of the sample) would give another view of its reality.

For future work and research, the use of logistic regression in the analysis may add some degree of ease of use of the PERM model because logistic regression is much more relaxed and flexible in the assumptions than DFA, logistic regression does not require the independent variable to be normally distributed, nor linearly related. It does, however, require a large sample size. 


\section{Conclusion}

By utilizing the PERM model with the two constructs PEER and POER and with its exploratory power (covering the perspective of innovation, management, organization, and environment), the study has addressed the following questions: - What is the current level of eCommerce adoption in Saudi Arabia? And - what is the group of factors or determinants that affects the decision of adoption and the level of adoption?

In general, the findings of the study can be summarized into two conclusions:

i. In Saudi Arabia, the environmental factors are more likely to affect the initial adoption of eCommerce, which is a stage of "I am there! I am online but not generating online revenue", so it is a way of the firm saying, "I hear the environment - the market forces, the supporting industry evolving, the governmental direction and regulations."

ii. As firms seek a more advanced form of eCommerce adoption, then the internal organizational factors become the main determinants for such decision, and on top of these factors are the technology resources, followed by commitment, awareness, and governance. One of the external factors, then, is placing considerable importance for such decision, the market force eReadiness, which represents the required ability to adapt to the market changes and customer needs.

\section{References}

Ajzen, I. (1985). From intentions to actions: A theory of planned behavior. In J. Kuhl and J. Beckmann (eds.), Action Control: From Cognition to Behavior. New York: Springer.

Barney, J.B. (1991). Firm resources and sustained competitive advantage. Journal of Management, 17, pp. 99-120. doi:10.1177/014920639101700108, http://dx.doi.org/10.1177/014920639101700108

Beatty, R.C., Shim, J.P., \& Jones, M.C. (2001). Factors influencing corporate web site adoption: a time based assessment. Information \& Management, pp. 337-354. doi:10.1016/S0378-7206(00)00064-1, http://dx.doi.org/10.1016/10.1016/S0378-7206(00)00064-1

Chatterjee, D., Grewal, R., \& Sambamurthy, V. (2002). Shaping up for e-Commerce: institutional enablers of the organizational assimilation of web technologies. MIS Quarterly, 26, pp. 65-89.

Claycomb, C., Iyer, K., \& Germain, R. (2005). Predicting the level of B2B eCommerce in industrial organizations. Industrial Marketing Management, 34, pp. 221-234. doi:10.1016/j.indmarman.2004.01.009, http://dx.doi.org/10.1016/j.indmarman.2004.01.009

Daniel, E.M., \& Grimshaw, D.J. (2002). An exploratory comparison of electronic commerce adoption in large and small enterprises. Journal of Information Technology, 17, pp.133-147. doi:10.1080/0268396022000018409, http://dx.doi.org/10.1080/0268396022000018409

Davis, C.H. (1999). The rapid emergence of electronic commerce in a developing region: the case of Spanish-speaking Latin America. Journal of Global Information Technology Management, 2, 25-40.

Davis, F.D. (1989). Perceived usefulness, perceived ease of use, and end user acceptance of information technology. MIS Quarterly, 13, 319-340

Enns, H.G., \& Huff, S.L. (1999). Information technology implementation in developing countries: advent of the Internet in Mongolia. Journal of Global Information Technology Management, 2, 5-24.

Gibbs, J., Kraemer, K.L., \& Dedrick, J. (2003). Environment and policy factors shaping global eCommerce diffusion: a cross-country comparison. The Information Society, 19, pp. 5-18. doi:10.1080/01972240309472, http://dx.doi.org/10.1080/01972240309472

Goode, S., \& Stevens, K. (2000). An analysis of the business characteristics of adopters and non-adopters of WWW. Information Technology and Management, 1, pp. 129-154. doi:10.1023/A:1019112722593, http://dx.doi.org/10.1023/A:1019112722593

Hemple, P.S., \& Kwong, Y.K. (2001). B2B eCommerce in emerging economies: i-metal.com's non-ferrous metals exchange in China. Journal of Strategic Information Systems, 10, pp. 335-355. doi:10.1016/S0963-8687(01)00058-0, http://dx.doi.org/10.1016/S0963-8687(01)00058-0

Jennex E. M., \& Amoroso D. (2004). eCommerce Infrastructure Success Factors for Small Businesses in developing countries. Electronic Commerce Research, 263 - 286. doi:10.1023/B:ELEC.0000027983.36409.d4, http://dx.doi.org/10.1023/B:ELEC.0000027983.36409.d4

Jennex, M.E., \& Amoroso, D.L. (2002). e-Business and technology issues for developing economies: a Ukraine case study. Electronic Journal of Information Systems in Developing Countries, 10, pp. 1-14.

Kenneth Laudon, Carol Traver, eCommerce (Business, Technology, Society) book.

Kshetri, N., \& Dholakia, N. (2002). Determinants of the global diffusion of B2B E-commerce. Electronic Markets, 12, pp. 120-129. doi:10.1080/10196780252844562, http://dx.doi.org/10.1080/10196780252844562

Kuan, K.K.J., \& Chau, P.Y.K. (2001). A perception-based model for EDI adoption in small businesses using a 
technology-organization environment framework. Information \& Management, 38, p. 507. doi:10.1016/S0378-7206(01)00073-8, http://dx.doi.org/10.1016/S0378-7206(01)00073-8

Mehrtens, J., Cragg, P.B., \& Mills, A.M. (2001). A model of Internet adoption by SMEs, Information \& Management, $\quad 39, \quad$ pp. $165-176 . \quad$ doi:10.1016/S0378-7206(01)00086-6, http://dx.doi.org/10.1016/S0378-7206(01)00086-6

Molla, A., \& Licker, P.S. (2005). eCommerce adoption in developing countries: a model and instrument, Information \& Management, 42, 877-899. doi:10.1016/j.im.2004.09.002, http://dx.doi.org/10.1016/j.im.2004.09.002

(2005). Perceived E-Readiness factors in Ecommerce adoption: an empirical investigation in a

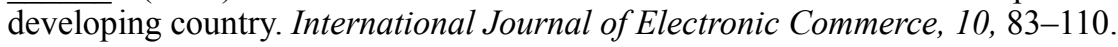

Moodley, S., \& Morris, M. (2004). Does eCommerce fulfill its promise for developing country (South African) garment export producers? Oxford Development Studies, 32, 155-178. doi:10.1080/13600810410001699939, http://dx.doi.org/10.1080/13600810410001699939

Mukti, N.A. (2000). Barriers to putting businesses on the Internet in Malaysia. Electronic Journal of Information Systems in Developing Countries, 2, pp. 1-6

Rogers, E.M. (1995). Diffusion of Innovation, 4th ed. The Free Press, New York.

Tornatzkym L.G., \& Fleischer, M. (1990). The Process of Technological Innovation. Lexington Books, Lexington, MA.

Xu, S., Zhu, K., \& J. Gibbs. (2004). Global technology, local adoption: across-country investigation of Internet adoption by companies in the United States and China. Electronic Markets, 14, pp.13-24. doi:10.1080/1019678042000175261, http://dx.doi.org/10.1080/1019678042000175261

Xuan, W. (2007). Factors affecting the achievement of success in e-tailing in China's retail industry: a case study of the Shanghai Brilliance Group. DBA thesis, Southern Cross University, Lismore, NSW.

Zhu, K., \& Kraemer, K.L. (2005). Post-adoption variations in usage and value of E-Business by organizations: cross-country evidence from the retail industry. Information Systems Research, 16, pp. 61-84. doi:10.1287/isre.1050.0045, http://dx.doi.org/10.1287/isre.1050.0045

Table 1. The distribution based on industry type

\begin{tabular}{|l|l|}
\hline Respondents' Sector & $\%$ \\
\hline Financial and insurance & $10.1 \%$ \\
\hline Tourist and transportation & $1 \%$ \\
\hline ICT services and products & $28.3 \%$ \\
\hline Energy and utilities & $11.1 \%$ \\
\hline Real-estate and construction & $4 \%$ \\
\hline Retail & $28.5 \%$ \\
\hline Petrochemicals & $11 \%$ \\
\hline Health (pharmaceutical and medical goods) & $6 \%$ \\
\hline
\end{tabular}

Table 2. The status or the level of eCommerce adoption in Saudi Arabia

\begin{tabular}{|l|c|c|c|}
\hline \multicolumn{4}{|c|}{ Case Processing Summary } \\
\hline & & No. of cases & Marginal Percentage \\
\hline EAD & 2 "email" & 6 & $6.5 \%$ \\
\cline { 2 - 4 } & 3 "Static Site" & 14 & $15.2 \%$ \\
\cline { 2 - 4 } & 4 "Interactive" & 25 & $27.2 \%$ \\
\cline { 2 - 4 } & 5 "Transactive" & 16 & $17.4 \%$ \\
\cline { 2 - 4 } & 6 "Integrated" & 31 & $33.7 \%$ \\
\hline Valid & & 92 & $100.0 \%$ \\
\hline Missing & & 0 & \\
\hline Total & & 92 & \\
\hline
\end{tabular}


Table 3. The coefficient alpha and item-scale correlations (Item Analysis)

\begin{tabular}{|c|c|c|c|c|}
\hline \multicolumn{5}{|c|}{ Item analysis: Item-Total Statistics } \\
\hline & $\begin{array}{c}\text { Scale Mean if Item } \\
\text { Deleted }\end{array}$ & $\begin{array}{c}\text { Scale Variance if Item } \\
\text { Deleted }\end{array}$ & $\begin{array}{c}\text { Corrected Item-Total } \\
\text { Correlation }\end{array}$ & $\begin{array}{c}\text { Cronbach's Alpha if } \\
\text { Item Deleted }\end{array}$ \\
\hline \multicolumn{5}{|c|}{ Organizational } \\
\hline A1 & 153.74 & 606.986 & 0.591 & 0.952 \\
\hline A2 & 153.7 & 602.807 & 0.648 & 0.952 \\
\hline A3 & 153.62 & 609.095 & 0.674 & 0.952 \\
\hline A4 & 153.7 & 606.763 & 0.61 & 0.952 \\
\hline A5 & 153.52 & 607.967 & 0.583 & 0.952 \\
\hline A6 & 153.79 & 607.045 & 0.563 & 0.952 \\
\hline A7 & 153.95 & 607.283 & 0.524 & 0.952 \\
\hline $\mathrm{C} 1$ & 154.11 & 593.263 & 0.785 & 0.951 \\
\hline $\mathrm{C} 2$ & 154.25 & 592.981 & 0.764 & 0.951 \\
\hline $\mathrm{C} 3$ & 154.26 & 593.514 & 0.803 & 0.951 \\
\hline $\mathrm{C} 4$ & 154.34 & 596.226 & 0.762 & 0.951 \\
\hline $\mathrm{C} 5$ & 154.24 & 594.843 & 0.755 & 0.951 \\
\hline G1 & 154.34 & 599.742 & 0.675 & 0.951 \\
\hline $\mathrm{G} 2$ & 154.23 & 602.991 & 0.708 & 0.951 \\
\hline G3 & 154.38 & 601.645 & 0.672 & 0.951 \\
\hline G4 & 154.32 & 596.108 & 0.734 & 0.951 \\
\hline G5 & 154.39 & 601.45 & 0.657 & 0.952 \\
\hline G6 & 154.37 & 600.609 & 0.682 & 0.951 \\
\hline G7 & 154.5 & 596.802 & 0.746 & 0.951 \\
\hline G8 & 154.18 & 608.284 & 0.542 & 0.952 \\
\hline HR1 & 153.32 & 611.537 & 0.493 & 0.952 \\
\hline HR2 & 153.66 & 624.006 & 0.194 & 0.954 \\
\hline BR1 & 153.92 & 615.763 & 0.394 & 0.953 \\
\hline BR2 & 153.97 & 611.878 & 0.449 & 0.953 \\
\hline BR3 & 153.91 & 608.366 & 0.508 & 0.952 \\
\hline BR4 & 154.36 & 611.991 & 0.531 & 0.952 \\
\hline BR5 & 154.11 & 624.34 & 0.232 & 0.954 \\
\hline BR6 & 153.79 & 606.825 & 0.537 & 0.952 \\
\hline TR1 & 153.42 & 608.489 & 0.587 & 0.952 \\
\hline TR2 & 153.6 & 599.034 & 0.684 & 0.951 \\
\hline TR3 & 153.15 & 614.328 & 0.496 & 0.952 \\
\hline TR4 & 153.14 & 611.573 & 0.57 & 0.952 \\
\hline TR5 & 153.57 & 605.721 & 0.597 & 0.952 \\
\hline TR6 & 153.63 & 603.093 & 0.662 & 0.952 \\
\hline \multicolumn{5}{|l|}{ External } \\
\hline MFeR1 & 153.72 & 617.348 & 0.379 & 0.953 \\
\hline MFeR2 & 153.6 & 619.935 & 0.358 & 0.953 \\
\hline GVeR1 & 154.03 & 614.054 & 0.408 & 0.953 \\
\hline GVeR2 & 154.27 & 614.024 & 0.425 & 0.953 \\
\hline GVeR3 & 154.11 & 618.603 & 0.385 & 0.953 \\
\hline GVeR4 & 154.13 & 614.005 & 0.38 & 0.953 \\
\hline SIeR1 & 153.55 & 618.733 & 0.36 & 0.953 \\
\hline SIeR2 & 153.68 & 620.24 & 0.314 & 0.953 \\
\hline SIeR3 & 153.6 & 618.99 & 0.381 & 0.953 \\
\hline SIeR4 & 153.99 & 614.692 & 0.38 & 0.953 \\
\hline SIeR5 & 154.02 & 619.428 & 0.296 & 0.954 \\
\hline
\end{tabular}


Table 4. Tests of Equality of Group Means

\begin{tabular}{|c|c|c|c|c|c|}
\hline \multicolumn{6}{|c|}{ Tests of Equality of Group Means } \\
\hline & Wilks' Lambda & F & df1 & df2 & Sig. \\
\hline POER & 0.758 & 14.216 & 2 & 89 & 0.000 \\
\hline PEER & 0.821 & 9.669 & 2 & 89 & 0.000 \\
\hline
\end{tabular}

Table 5. Box's M test

\begin{tabular}{|c|c|c|}
\hline \multicolumn{3}{|c|}{ Test Results } \\
\hline \multicolumn{2}{|c|}{ Box's M } & 18.452 \\
\hline \multirow[t]{4}{*}{$\mathrm{F}$} & Approx. & 2.798 \\
\hline & df1 & 6 \\
\hline & df2 & $1.257 \mathrm{E} 3$ \\
\hline & Sig. & 0.01 \\
\hline
\end{tabular}

Table 6. Significance Table

\begin{tabular}{|l|r|r|r|c|}
\hline \multicolumn{5}{|c|}{ Wilks' Lambda } \\
\hline Test of Function(s) & Wilks' Lambda & Chi-square & \multicolumn{1}{c|}{ Df } & \multicolumn{1}{c|}{ Sig. } \\
\hline 1 through 2 & 0.647 & 38.59 & 4 & 0.000 \\
\hline 2 & 0.862 & 13.17 & 1 & 0.000 \\
\hline
\end{tabular}

Table 7. Structure Matrix (disciminant loading)

\begin{tabular}{|c|c|c|}
\hline \multicolumn{3}{|c|}{ Structure Matrix } \\
\hline & \multicolumn{2}{|c|}{ Function } \\
\hline & 1 & 2 \\
\hline POER & $.961^{*}$ & -0.278 \\
\hline PEER & 0.574 & $.819^{*}$ \\
\hline
\end{tabular}

Table 8 . Test of equality

\begin{tabular}{|l|r|r|r|r|r|}
\hline \multicolumn{7}{|c|}{ Tests of Equality of Group Means } \\
\hline & Wilks' Lambda & F & df1 & df2 & Sig. \\
\hline A & 0.785 & 12.153 & 2 & 89 & 0.000 \\
\hline C & 0.776 & 12.817 & 2 & 89 & 0.000 \\
\hline G & 0.812 & 10.32 & 2 & 89 & 0.000 \\
\hline HR & 0.928 & 3.428 & 2 & 89 & 0.037 \\
\hline BR & 0.967 & 1.499 & 2 & 89 & 0.229 \\
\hline TR & 0.72 & 17.292 & 2 & 89 & 0.000 \\
\hline MFeR & 0.817 & 9.951 & 2 & 89 & 0.000 \\
\hline GVeR & 0.928 & 3.447 & 2 & 89 & 0.036 \\
\hline SIeR & 0.89 & 5.487 & 2 & 89 & 0.006 \\
\hline
\end{tabular}

Table 9. Test the assumption of homogeneity of covariance matrices

\begin{tabular}{|l|l|r|}
\hline \multicolumn{2}{|c|}{ Test Results } \\
\hline \multicolumn{2}{|c|}{ Box's M } & 116.101 \\
\hline \multirow{3}{*}{ F } & Approx. & 2.282 \\
\cline { 2 - 3 } & df1 & 45 \\
\cline { 2 - 3 } & df2 & 21560 \\
\cline { 2 - 3 } & Sig. & 0.000 \\
\hline
\end{tabular}

Table 10. Significance Table

\begin{tabular}{|l|c|c|c|c|}
\hline \multicolumn{5}{|c|}{ Wilks' Lambda } \\
\hline Test of Function(s) & Wilks' Lambda & Chi-square & df & Sig. \\
\hline 1 through 2 & 0.518 & 55.935 & 18 & 0.000 \\
\hline 2 & 0.832 & 15.615 & 8 & 0.048 \\
\hline
\end{tabular}


Table 11. Structure Matrix (discriminant loading)

\begin{tabular}{|l|c|c|}
\hline \multicolumn{3}{|c|}{ Structure Matrix } \\
\hline & \multicolumn{2}{|c|}{ Function } \\
\hline & 1 & 2 \\
\hline TR & $.796^{*}$ & -0.145 \\
\hline C & $.676^{*}$ & -0.23 \\
\hline A & $.659^{*}$ & -0.214 \\
\hline G & $.617^{*}$ & -0.061 \\
\hline HR & $.345^{*}$ & -0.152 \\
\hline SieR & 0.259 & $.639^{*}$ \\
\hline MFeR & 0.498 & $.601^{*}$ \\
\hline GveR & 0.226 & $.479^{*}$ \\
\hline BR & 0.188 & $-.247^{*}$ \\
\hline
\end{tabular}

* Largest absolute correlation between each variable and any discriminant function

Table 12. Structure Matrix (disciminant loading)

\begin{tabular}{|c|c|}
\hline \multicolumn{2}{|c|}{ Description of the variables in the PERM[1] } \\
\hline Variables & Description \\
\hline \multicolumn{2}{|c|}{ Perceived organizational eReadiness (POER) } \\
\hline Awareness & $\begin{array}{l}\text { Represents perception of eCommerce elements in the environment; comprehension of their } \\
\text { meaning through an understanding of eCommerce technologies, business models, requirements, } \\
\text { benefits and threats and projection of the future trends of eCommerce and its impact. }\end{array}$ \\
\hline Commitment & $\begin{array}{l}\text { Reflects enough energy and support for eCommerce from all corners of an organization and } \\
\text { especially from the strategic apex. It refers to having a clear-cut eCommerce vision and strategy } \\
\text { championed by top management, eCommerce leadership and organization wide support of } \\
\text { eCommerce ideas and projects. }\end{array}$ \\
\hline Human resources & $\begin{array}{l}\text { Refers to the availability (accessibility) of employees with adequate experience and exposure to } \\
\text { information and communications technology (ICT) and other skills (such as marketing, business } \\
\text { strategy) that are needed to adequately staff eCommerce initiatives and projects. }\end{array}$ \\
\hline $\begin{array}{l}\text { Technological } \\
\text { resources }\end{array}$ & $\begin{array}{l}\text { Refers to the ICT base of an organization and assesses the extent of computerization, the } \\
\text { flexibility of existing systems and experience with network based applications }\end{array}$ \\
\hline $\begin{array}{l}\text { Business } \\
\text { resources }\end{array}$ & $\begin{array}{l}\text { This covers a wide range of capabilities and most of the intangible assets of the organization. It } \\
\text { includes the openness of organizational communication; risk-taking behavior, existing business } \\
\text { relationships, and funding to finance eCommerce projects. }\end{array}$ \\
\hline Governance & $\begin{array}{l}\text { The strategic, tactical and operational model organizations in developing countries put in place to } \\
\text { govern their business activities and eCommerce initiatives. }\end{array}$ \\
\hline \multicolumn{2}{|c|}{ Perceived external eReadiness (PEER) } \\
\hline $\begin{array}{l}\text { Government } \\
\text { eReadiness }\end{array}$ & $\begin{array}{l}\text { Organizations' assessment of the preparation of the nation state and its various institutions to } \\
\text { promote, support, facilitate and regulate eCommerce and its various requirements. }\end{array}$ \\
\hline $\begin{array}{l}\text { Market forces } \\
\text { eReadiness }\end{array}$ & $\begin{array}{l}\text { The assessment that an organization's business partners such as customers and suppliers allow an } \\
\text { electronic conduct of business. }\end{array}$ \\
\hline $\begin{array}{l}\text { Supporting } \\
\text { industries } \\
\text { eReadiness }\end{array}$ & $\begin{array}{l}\text { Refers to the assessment of the presence, development, service level and cost structure of } \\
\text { support-giving institutions such as telecommunications, financial, trust enablers and the IT } \\
\text { industry, whose activities might affect the eCommerce initiatives of businesses in developing } \\
\text { countries. }\end{array}$ \\
\hline \multicolumn{2}{|c|}{ eCommerce adoption } \\
\hline $\begin{array}{l}\text { Initial eCommerce } \\
\text { adoption }\end{array}$ & $\begin{array}{l}\text { A business is considered to have adopted eCommerce if it has achieved an interactive eCommerce } \\
\text { status. }\end{array}$ \\
\hline $\begin{array}{l}\text { Institutionalization } \\
\text { of eCommerce }\end{array}$ & $\begin{array}{l}\text { Indicates whether or not an organization has attained an interactive, or transactive or integrated } \\
\text { eCommerce status. }\end{array}$ \\
\hline
\end{tabular}




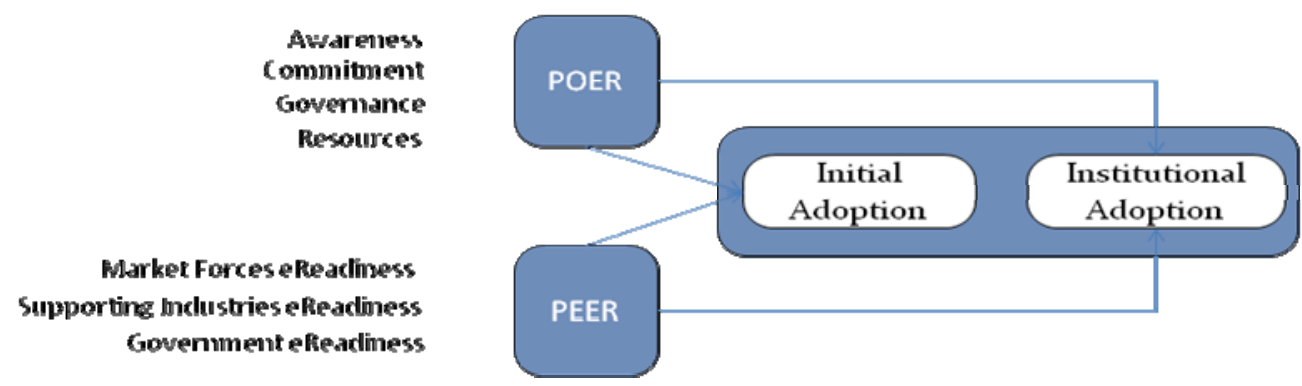

Figure 1. PERM 